\title{
Effect of Management Commitment to Service Quality on Car-hailing Drivers' Service Behaviors: The Case of GrabCar in Vietnam
}

\author{
Phuong TRAN HUY, Hong Chuong PHAM
}

\author{
National Economics University, Hanoi, Vietnam, phuongth@neu.edu.vn; chuongph@neu.edu.vn
}

\begin{abstract}
Background and Purpose: Management Commitment to Service Quality (MSCQ) has been found to positively predict employee's service quality and service behaviors in different service industries. In the context of sharing economy, the relationship between company and service providers is different from traditional employment relationship. For car-hailing service, drivers are mainly classified as contractors rather than employees. It is, therefore, necessary to understand whether MSCQ influences drivers' service quality in a car-hailing context.

Design/Methodology/Approach: Data were collected from $214 \mathrm{GrabCar}$ drivers in Vietnam using online and offline survey. Partial Least Squares Structural Equation Modeling (PLS-SEM) was used for data analysis.

Results: The findings suggest that three dimensions of MCSQ, namely reward system, technology support and organizational support exert significant direct impact on drivers' service behaviors. In addition, job involvement plays an intermediary role in the relationship between MCSQ and service behaviors.

Conclusion: This study expands previous research on MCSQ to the car-haling service and confirms the role of job involvement as an important mechanism to improve service quality provided by drivers. Due to the characteristics of the company-service providers' relationship in the sharing economy, the mechanisms through which MCSQ influences providers' service performance need to be investigated in further details.
\end{abstract}

Keywords: Management commitment to service quality (MCSQ), Service behaviors, Job involvement, Car-hailing, Sharing economy, Vietnam.

\section{Introduction}

In the context of sharing economy, a number of businesses have emerged and proliferated (Peticca-Harris et al., 2018). In transportation, car-hailing service companies such as Uber, Lyft and Zipcar have expanded and gained significant market share throughout the world. Ride-sharing or Car-hailing typically refers to hire services where a passenger books for a ride using an online/ mobile platform. This type of sharing can happen when a driver shares his private vehicle with a passenger in a more open taxilike system (Amey et al., 2011). By 2017, Uber was in use in 507 cities throughout the world and has an estimated market value of over $\$ 68$ billion (Çetin, 2017). In China, Didi Chuxing (DiDi), have been successful in the transportation market, overtaking Uber's four billion rides in 2017 (Zuo, et al., 2019). In other markets, Transport Network Companies (TNCs) such as GrabCar and Go-jek have also achieved remarkable market growth (Hamenda, 2019).

The focus of the current study is on car-hailing service, namely GrabCar, provided by Grab Inc in Vietnam. Formerly known as MyTeksi and GrabTaxi, Grab is a Singapore based ride-sharing company. The company was originally founded in Malaysia and later moved its headquarters to Singapore. Grab is an app-based service provider that offers ride-hailing, ride-sharing, and logistics

Received: 7th November 2020; revised: 23rd February 2021; accepted: 11th March 2021 
services through its app. It now operates in the Southeast Asian countries of Singapore, Malaysia, Indonesia, Philippines, Vietnam, Thailand, Myanmar, Cambodia and Japan. Grab has been operating in Vietnam since 2014 with the original name Grabtaxi. Current transportation services include GrabCar, GrabTaxi and GrabBike. According to ABI research (2019), Grab dominates the car-hailing market in Vietnam with about $73 \%$ market share, 5 times more than that of its closest rival. In 2019, it is estimated that Grab has attracted about 135,000 drivers, more than 50,000 of whom are car drivers.

Despite its high potential, car-hailing services are not without problems, with service quality being the most prominent (Rayle, et al., 2016). Rayle et al. (2016) concerned that poor service quality may result because riders cannot compare information on price or service quality before choosing a vehicle. Yang et al. (2017) indicated that low industry expertise, lack of professional training, and loose obligations with the sharing service organizers are among the sources for low quality service provided by TNCs. Both Katz (2015) and Zuo et al. (2019) seemed to agree that, it is the business model, in which TNCs such as Uber have no employment relationship with direct service providers (drivers), and no financial stake in any particular transaction that cause service problems.

Because service quality is the most critical success factor for service (Frei, 2008), TNCs have find ways to provide better services to their customers. However, because of the loose nature of the relationship between TNCs and drivers, managing the ride service quality provided by contracted drivers is a challenging tasks (Shokoohyar, Sobhani, and Nargesi, 2020). The current study aims to address the following research questions: (a) "What should online platforms do to improve service quality offered to customers by their drivers?" and (b) "Through what channels do management' actions influence drivers' service delivery?"

The current study proposes that a TNC's management commitment to service quality (MCSQ) would influence car-hailing driver's service, despite the striking difference between car-hailing and traditional employment context. In addition, unlike in traditional employment context, where organizational commitment may act as a mediator of the relationship between firm commitment to service quality and provided service, this paper advocates that in the car-hailing context, job involvement would mediate the above relationship.

The contribution of this paper is threefold. First, while service quality has already attracted plentiful research interests, Priporas et al. (2017) and Zuo et al. (2019) proposed that empirical research about service quality in the sharing economy context in general, and online car-hailing industry, in particular, are still scarce. Furthermore, most extant studies examined the dimensions of service quality or investigated it as an antecedent of consumer satisfaction (Ahrholdt, et al. 2017; Priporas et al., 2017; An et al., 2019). To date, little research investigates the antecedents of service quality in the sharing economy. In addition, while many studies observe service quality from the users' perspective (Dias et al., 2017; Ju et al., 2018; Priporas et al., 2017), few studies take the perspective of the direct service providers. Extant studies that focus on the supply side of car-hailing service mostly focus on factors that influence drivers' supply of service such as fare policy (Shokoohyar, 2018) or socio-economics factors and transportation infrastructures (Shokoohyar, Sobhani and Sobhani, 2020). This research takes a different focus by investigating service quality provided by car-hailing drivers.

Second, while the impact of management commitment to service quality on service performance has been investigated in the universal organizational context (Ashill et al., 2008; Babakus et al. 2003; Kim et al., 2009), few research focus on the sharing economy context in general and car-hailing service in particular. In addition, Lin et al., (2020) argued that because the determinants of workers' performance in the sharing economy have been scarce, more research attention to explore the driving mechanism of such workers' performance is needed. Similarly, Gleim et al. (2019) acknowledged a clear gap in our understanding of the perceptions and work outcomes of sharing economy workers and emphasize the importance of addressing this gap as the sharing economy continues to grow.

Third, this research explores the mediating impact of job involvement on the relationship between MCSQ and service performance. In the car-hailing context, because of the usually temporary and short term, non-employment relationship between TNCs and their direct service providers (Yang et al., 2017; Karn \& Hutson, 2019) we expect that organizational commitment would not act as an intermediary variable of the MCSQ-service performance linkage. Peticca-Harris, et al. (2018) studied the motivations and experiences of Uber drivers in Canada. Data collected from 31 drivers, divided into part-time, full-time non-professional and full time professional group, indicate that drivers do not think about a long-term future with Uber. Instead, the drivers reported that driving for Uber is a temporary solution. Specifically, part-time drivers consider working for Uber as a part-time job for some extra income, while looking for more attractive future opportunities elsewhere. They also regard "driver" as an unwanted occupation and they prefer Uber because it is easier to quit Uber than traditional taxi. Full-time non-professional drivers do not regard driving as an occupational choice, yet they have to drive to make ends meet, showing some extent of continuance commitment to the company. Finally, while full-time professional drivers accept driving as their profession, they only opt for Uber for flexibility and potentially better income in comparison with traditional taxi companies. In a recent study, Lin et al. (2020) proposed that because of the flexibility that allows drivers to work 
for multiple online platforms simultaneously, commitment should not be viewed from organizational perspective. Instead, they advocated the use of career commitment, which refers to the "relative strength of an individual's identification with and involvement" with car-hailing sector in the sharing economy. The current study, examines job involvement of car-hailing drivers as a possible mechanism to deliver the impact of MSCQ on service quality.

\section{Literature review}

\subsection{Management commitment to service quality}

Extant literature has confirmed the role of managerial practices in fostering service behaviors among service workers (Kandampully \& Menguc, 2000; Ueno, 2008). Managerial practices that contribute to excellent service quality can be conceptualized as management commitment to service quality (Babakus et al., 2003; Karatepe \& Karadas, 2012; Rod \& Ashill, 2010). Babakus et al. (2003, p. 275) defined management commitment to service quality (MCSQ) as “employees' appraisal of an organization's commitment to nurture, develop, support, and reward its employees to achieve service excellence". Previous research suggested that MCSQ comprises practices such as training, empowerment and reward (Babakus et al., 2003), service technology, supportive management and servant leadership (Ashill et al., 2008), customer service orientation (Rod and Ashill, 2010), and organizational support (Kim et al., 2009). MCSQ has been found to positively predict employee's service recovery performance and service behaviors in different service industries including banking (Babakus, et al., 2003), hospitality (Karatepe \& Karadas, 2012), healthcare (Rod \& Ashill, 2010), and public service (Ashill et al. 2008). In the context of car-hailing, because the drivers are mainly classified as contractors rather than employees (Rosenblat \& Stark, 2016; Rosenblat, et al., 2017), they have total autonomy in their work, receive no service training and do not report to a particular leader. Therefore, MCSQ in this context should not include training, leadership and empowerment. In the current study, MCSQ includes service performance-based reward system, service technology and perceived organizational support.

\subsection{Job involvement}

Job involvement refers to the degree to which individuals psychologically identify with their present job (Kanungo, 1982). According to Kanungo (1982), job involvement and work involvement are different constructs. While job involvement focuses on one's identification with the cur- rent job and is influenced by the extent to which the current job can satisfy present needs, work involvement refers to the value of work in an individual's entire life and is a function of past experience. Because car-hailing drivers do not regard the car-hailing job as a career or a long term commitment (Karn \& Hutson, 2019), and most of them have worked in other jobs (Valente, Patrus, \& Guimarães, 2019), this study focuses on job involvement of GrabCar drivers.

Research provides evidences to support the desirability of job involvement in the workplace. For example, people with high job involvement tend to develop strong tie with their jobs and are willing invest "personal resources" in their current job (Dimitriades, 2007; Kanungo, 1982). On the other hand, studies have found that employees with a low degree of job involvement tend to lose focus on their job (Hogan et al., 2013), and are less imaginative and open to new concepts (Abdallah et al., 2016).

\section{Theoretical framework and hypotheses}

\subsection{Impact of management commitment on service quality and service behavior}

\section{Reward system}

The impact of organizational reward on service performance has been well documented in the literature. Parasuraman (1987) argued that in order to distinguish a firm's services from others, rewarding innovative thinking, outstanding service behaviors, and excellence in service delivery is vital. Similarly, Yavas et al. (2003) proposed that reward is not only important in fostering excellent service but also crucial in motivating direct service providers to solve service complaints.

In ride-hailing service, TNCs implement positive and punitive reward systems toward direct service providers. For instance, Uber offers rewards to its drivers if they achieve a pre-specified number of trips per week (Shokoohyar, 2018). In addition, Uber introduces reward program such as Uber Pro which offers such benefit as priority pickups, supports on the road, and family benefit based on numbers of trips and rider ratings (Uber, 2020). Similar reward programs have been applied by Grab who bases driver benefits on monthly rides, completion rate and star rating (Grab, 2019). On the other hand, car hailing companies also offer punitive reward program. For example, ride-hail companies require a driver to maintain a minimum rating, completion rate and driver timeout. Drivers are penalized if they go below the required completion rate. If a driver excessively ignores or cancels booking requests, they 
Table 1: Summary of MCSQ studies

\begin{tabular}{|c|c|c|c|c|}
\hline Study & MSCQ practices & Dependent variable & Mediator & Sample \\
\hline $\begin{array}{l}\text { Kandampully and } \\
\text { Menguc (2000) }\end{array}$ & $\begin{array}{l}\text { Quality control practices; } \\
\text { quality measurement prac- } \\
\text { tices; and service mainte- } \\
\text { nance practices }\end{array}$ & Service quality & None & Service firms \\
\hline $\begin{array}{l}\text { Babakus et al. } \\
\qquad(2003)\end{array}$ & $\begin{array}{c}\text { Training, empowerment, } \\
\text { and rewards }\end{array}$ & $\begin{array}{l}\text { Service recovery perfor- } \\
\text { mance }\end{array}$ & $\begin{array}{l}\text { Affective com- } \\
\text { mitment } \\
\text { Job satisfaction }\end{array}$ & $\begin{array}{l}\text { Frontline bank } \\
\text { employees }\end{array}$ \\
\hline $\begin{array}{l}\text { Yavas, Karatepe, } \\
\text { Avci, and Tekinkus } \\
\text { (2003) }\end{array}$ & $\begin{array}{l}\text { Service orientation, re- } \\
\text { ward, training, empower- } \\
\text { ment, and teamwork }\end{array}$ & $\begin{array}{l}\text { Service recovery perfor- } \\
\text { mance }\end{array}$ & None & $\begin{array}{l}\text { Frontline bank } \\
\text { employees }\end{array}$ \\
\hline $\begin{array}{l}\text { Lee, Barker, and } \\
\text { Kandampully } \\
\text { (2003) }\end{array}$ & Technology support & Service quality & & Hotel managers \\
\hline $\begin{array}{l}\text { Ashill, Rod, and } \\
\text { Carruthers (2008) }\end{array}$ & $\begin{array}{l}\text { Training, empowerment, } \\
\text { rewards, supportive } \\
\text { management, servant } \\
\text { leadership, and service } \\
\text { technology. }\end{array}$ & $\begin{array}{l}\text { Service recovery perfor- } \\
\text { mance and turnover } \\
\text { intentions. }\end{array}$ & $\begin{array}{l}\text { Job satisfaction } \\
\text { and organiza- } \\
\text { tional commit- } \\
\text { ment }\end{array}$ & $\begin{array}{l}\text { Public sector } \\
\text { service frontline } \\
\text { employees }\end{array}$ \\
\hline $\begin{array}{l}\text { Kim, Tavitiyaman, } \\
\text { and Kim (2009) }\end{array}$ & $\begin{array}{l}\text { Organizational support, } \\
\text { rewards, empowerment, } \\
\text { and training }\end{array}$ & Service behaviors & Job satisfaction & Hotel employees \\
\hline $\begin{array}{l}\text { Rod and Ashill } \\
\qquad(2010)\end{array}$ & $\begin{array}{l}\text { Reward, training, em- } \\
\text { powerment, and service } \\
\text { orientation. }\end{array}$ & $\begin{array}{l}\text { Service recovery perfor- } \\
\text { mance }\end{array}$ & $\begin{array}{l}\text { Organizational } \\
\text { commitment. }\end{array}$ & $\begin{array}{l}\text { Frontline hospital } \\
\text { employees }\end{array}$ \\
\hline $\begin{array}{l}\text { Karatepe and } \\
\text { Karadas (2010) }\end{array}$ & $\begin{array}{l}\text { Training, empowerment, } \\
\text { and rewards }\end{array}$ & $\begin{array}{l}\text { Service recovery perfor- } \\
\text { mance and extra-role } \\
\text { customer service }\end{array}$ & $\begin{array}{l}\text { Job embedded- } \\
\text { ness }\end{array}$ & $\begin{array}{l}\text { Frontline hotel } \\
\text { employees }\end{array}$ \\
\hline
\end{tabular}

are locked out of the platform for a temporary period of time. Drivers with passenger complaints and low star ratings are also flagged and suspended (Grab, 2019). While many TNCs use riders' rating to base their reward system, drivers complain that they are not aware of what influence their ratings (Rosenblat \& Stark, 2016), and are doubtful about the link between ratings and benefits (Rosenblat et al., 2017). Ashill et al. (2008) advocated that if direct service providers believe that rewards systems and policies truly reflect commitment to service quality by management, they tend to engage themselves in service quality efforts. Thus, we can conclude that in order to improve service performance, reward structure should be perceived by drivers to be contingent upon service performance.

Hla: Service performance-based reward system is positively linked with service behaviors of car-hailing drivers

\section{Service technology support}

Service technology may aid service workers in providing better service to customers by optimizing pro- cess, making procedures accurate and efficient, removing time-consuming routine tasks and reducing human errors (Ashill et al., 2008; Lee et al., 2003). In car hailing service, TNCs provide drivers with technological support in the form of rudimentary dispatching and navigation through the company-provided mobile apps. According to Karn and Hutson (2019), while the app-based system is considered reliable, issues such as difficulty with driver-passenger meet-up due to GPS failures, or billing problems that neither the driver nor rider could resolve through the app's functions may reduce service performance. Thus, we can expect that the availability of technology service support will enable the drivers to focus on delivery transportation service. Based on the above arguments, it is hypothesized that:

H1b: Service technology support is positively linked with service behaviors of car-hailing drivers

\section{Perceived Organizational support}

Organizational support refers to an individual's per- 
ception that the organization is concerned about their success and well-being (Eisenberger et al., 1986). Organizational support has been a strong predictor of service performance (Ashill et al., 2008; Kim et al., 2009; Susskind et al., 2000). Ashill et al. (2008) argued that, based on the norm of reciprocity, service employees who receive support from their organization are likely to exert more efforts on their job in return. Susskind et al. (2000) indicated that organizational support is of great importance when dealing with service complaints. Because POS reflects workers' assessment of self-value by the hiring organization (Albalawi et al., 2019), service workers who receive support in such situations tend to build trust with the organization, which in turn, influence service efforts. In the context of car-hailing, support received by the drivers from the sharing platforms is one important area of interest. Karn and Hutson (2019) found that drivers receive little or no support in many aspects of work including vehicle ownership and maintenance, expenses tracking and deductions, and business finances. Karn and Hutson (2019) proposed that these lack of support influence drivers socially, behaviorally, financially, and emotionally. Shokoohyar (2018) also indicated that operational costs and lack of job security are the main concerns of drivers and suggested that providing more supportive incentive contract to compensate drivers' operational costs can improve drivers job satisfaction. Thus, we can expect that organizational support will foster efforts in service behaviors.

H1c: Perceived Organizational Support is positively linked with service behaviors of car-hailing drivers

\subsection{The impact of MCSQ on job involvement}

\section{Reward system}

Kanungo (1982, p.342) defined job involvement as "the degree that an individual psychologically identifies with his or her present job", and suggested that because job involvement concerns the present job, it is influenced by how much the present job can satisfy current needs. In car-hailing scenario, Standing et al. (2019) suggested that income, being independent, and lack of job opportunities are the main reasons to provide service. Valente et al. (2019) found that the main reason for becoming a car-hailing driver is to solve unemployment issues and to generate more income, rather than to make an adjustment to the market or a to search for more flexible and complementary type of work. Because reward structure that is contingent upon service performance can satisfy the current needs of generating income, it is expected to be positively linked with job involvement.

H2a: Service performance-based reward system positively influences a driver's job involvement

\section{Service technology support}

Technology support can help service employees carry out their job duties successfully. It frees the employees of routine repetitive tasks that may frustrate the employees. With the help of technology, the service workers can devote their time to deliver excellent service to the customers (Lytle et al., 1998). Technology support also makes the jobs less demanding and taxing by reducing job stress. Therefore, technology is expected to positively linked with job involvement. It is hypothesized that:

$H 2 b$ : Service technology support positively influences a driver's job involvement

\section{Perceived organizational support}

Researchers contended that the work environment has a significant impact on job involvement (Lawler \& Hall, 1970; Lawler, 1992). Lambert and Paoline (2012) suggested that positive aspects of work environment such as organizational support, can reduce job stress and make the job more enjoyable, thereby increases job involvement. In addition, when employees perceive that the organization is supportive and concerned about their success and well-being, they may consider it as a signal from the organization that it respects and values the jobs that they are doing. Organizational support may also contribute toward the fulfillment of "socio-emotional needs" of employees (Rhoades \& Eisenberger, 2002). Being successful and valued increases the likelihood that a person will identify with his or her job. In addition, fulfillment of needs also contributes to the feeling of attachment with the job. Therefore, it is hypothesized that:

H2c: Perceived organizational support positively influences a driver's job involvement

\subsection{The mediating role of job involvement}

Job involvement is identified as a predictor of important work outcomes, such as organizational commitment, job satisfaction, increased work effort, job performance, and organizational citizenship behaviors (Chen \& Chiu, 2009; Diefendorff, Brown, Kamin, \& Lord, 2002). Wood (1974) suggested that job involvement results from intrinsic motivation and therefore, is likely to be linked to job performance that provides intrinsic rewards. Abhari et al. (2019) study collaborative innovation in the sharing economy and found that beside extrinsic motivation such as financial gain, intrinsic motivation such as enjoyment and altruism are important determinants of engagement in social product development projects. Lin et al. (2020) research food delivery workers in the sharing economy 
and found that enjoyment attached with the job was an important work value perceived by these workers. In addition, they found a positive relationship between drivers' work centrality and work engagement, which in turn, foster positive work behaviors. Thus it can be expected that, in the context of sharing economy, job involvement is an important determinant of positive job outcomes among participants. Furthermore, the mediating impact of job in- volvement on the relationship between job characteristics and job performance has been confirmed in other contextual settings (Chen \& Chiu, 2009; Mrayyan \& Al-Faouri, 2008). Following these above argument, it is hypothesized that:

H3a-c: Job involvement mediates the relationship between reward system, service technology and perceived organizational support and service performance.

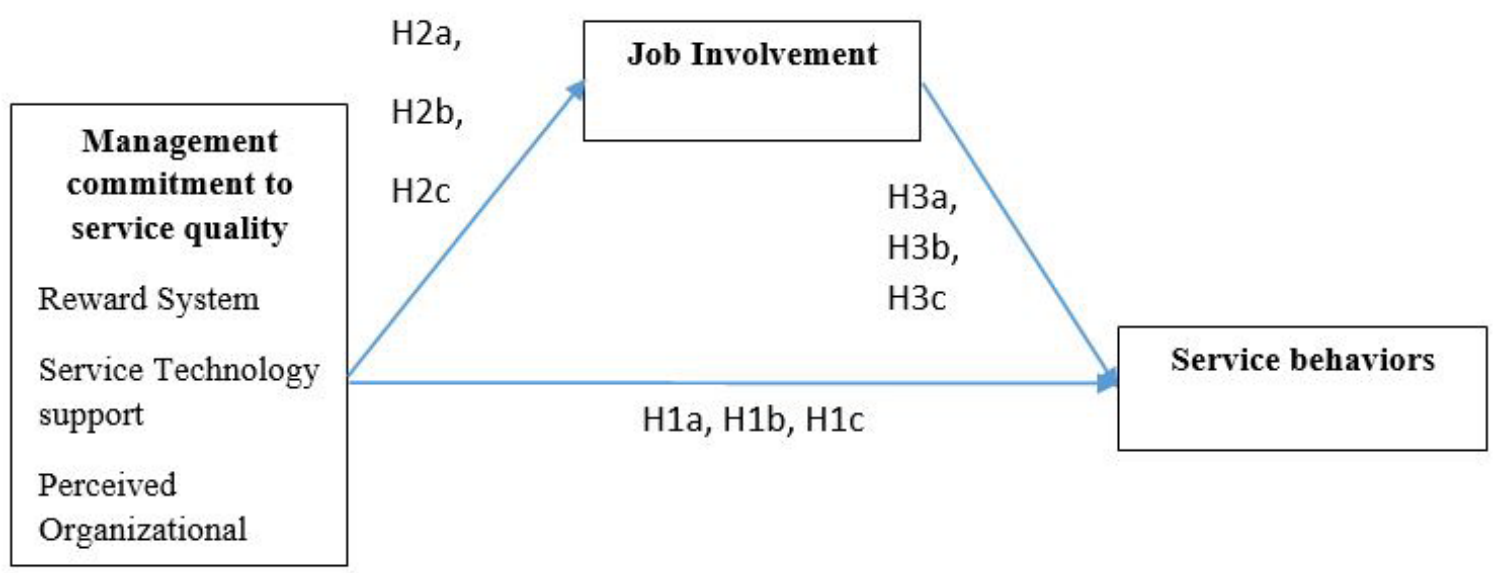

Figure 1: Research model

\section{Method}

\subsection{Data collection}

Preliminary interviews with 10 drivers were conducted by the author during 30-minute rides with Grab to understand the characteristics of the relationship between drivers and the TNC, the availability of technological support and job involvement of the drivers. Information obtained from interviews were used to develop questionnaires for a subsequent quantitative survey.

Quantitative data were collected via survey based on convenient sampling and snowball techniques due to unavailability of drivers' information. Questionnaires in paper-based or QR-coded versions were administered to Grab drivers by our research collaborators during their rides with Grab. Then, the drivers were requested to introduce other fellow drivers who are driving for Grab. Based on this information, we contacted other drivers and sent the QR-coded/online versions of the questionnaires. These drivers may choose whether to participate in the research. Out of 450 questionnaires sent, 214 have been filled by Grab drivers and were used for data analysis.

\subsection{Measure}

All items are measured on a 5-point Likert scale ranging from 1 . Strongly disagree to 5. Strongly agree, unless stated otherwise.

Service performance-based Reward system: respondents are asked to evaluate the degree to which reward are based on performance at Grab Vietnam. Three items used by Ashill et al. (2008) were adopted to measure employee reward. A sample item is "My income depends on the quality of service I deliver".

Service Technology Support: Drivers are requested to rate the extent to which technology support is offered by the company. This scale was measured using a four-item scale used by Ashill et al. (2008). The items include: "Grab has the necessary technology support to serve my customers effectively".

Perceived organizational support (POS): The drivers are asked to provide their self-perception of the support offered to them by Grab company. Eight items selected from the 16-item SPOS scale developed by Eisenberger et al. (1986) were used to measure POS in car-hailing background. Uses of shorter version was suggested by Rhoades and Eisenberger (2002) as acceptable. Shorter version of the scale has been used by Hameed et al. (2019). The items 
include "Grab is willing to help me when I need a special favor".

Job involvement: This variable measures the extent to which a driver is identified with their driving jobs. The 10item scale developed by Kanungo (1982) was adopted in this research. These items include: "The most important things that happen to me involve my present job" and "I live, eat and breathe my job".

Service behavior (SB): This variable measures the drivers' delivery of service to the customers. Five items adapted from Zhang et al. (2019) were used to measure service behavior. One sample item was "I provide transportation services according to the job responsibilities prescribed by Grab". The scale items are presented in the Appendix.

\section{Results}

\subsection{Sample description}

Among 214 drivers, 210 are men and only 4 are women. The average age of the drivers is 32.4 years. On average, the drivers have been in partnership with Grab for two and a half years. About $75 \%$ of the drivers bought a car to drive for Grab while the remaining 25\% used their under-utilized cars. Also, more than two-thirds of the respondents are working full-time as drivers. More than half of the respondents also drive for other ride-hailing platforms.

Table 2: Respondent profile

\begin{tabular}{|c|c|c|}
\hline Variable & Frequency & Percentage \\
\hline \multicolumn{3}{|l|}{ Gender of driver } \\
\hline Men & 210 & $98.1 \%$ \\
\hline Women & 4 & $1.9 \%$ \\
\hline \multicolumn{3}{|l|}{ Age of driver } \\
\hline From 18 to 25 & 64 & $29.9 \%$ \\
\hline From 26 to 35 & 75 & $35.1 \%$ \\
\hline From 36 to 45 & 41 & $19.2 \%$ \\
\hline Above 46 & 34 & $15.8 \%$ \\
\hline \multicolumn{3}{|l|}{ Year of working with Grab } \\
\hline Less than 1 year & 101 & $47.2 \%$ \\
\hline From one to 3 years & 74 & $34.6 \%$ \\
\hline More than 3 years & 39 & $18.2 \%$ \\
\hline \multicolumn{3}{|l|}{ Type of vehicle } \\
\hline Under utilized & 156 & $72.9 \%$ \\
\hline Newly bought & 58 & $27.1 \%$ \\
\hline \multicolumn{3}{|l|}{ Multiple TNCs } \\
\hline Drive only for Grab & 93 & $43.5 \%$ \\
\hline Drive for other TNCs & 121 & $56.5 \%$ \\
\hline
\end{tabular}

\subsection{Validity and reliability}

Before testing the hypotheses, we check the reliability and validity of the research variables. As indicated in figure 1 , all indicators showed significant loading values on their specified construct, and the standardized loadings ranged from .54 to .89 ( $\mathrm{t}$ values $=7.093$ to $39.77 ; \mathrm{p}<.001$ ). For reliability and convergence validity, Composite Reliability (CR) of all latent variables were calculated and compared to the threshold value of .7. The average variance extracted
(AVE) for all variables should also exceed the threshold value of .5 (Hair, Black, Babin, and Anderson, 2010).

For discriminant validity, the square roots of the all AVE scores should be higher than the correlation coefficients between the constructs (Fornell \& Larcker, 1981). Furthermore, Heterotrait-monotrait (HTMT) ratios must be smaller than 0.8. The figures shown in Table 3 and the fact that the highest HTMT ratio is 0.639 confirm the reliability and validity of the constructs. 


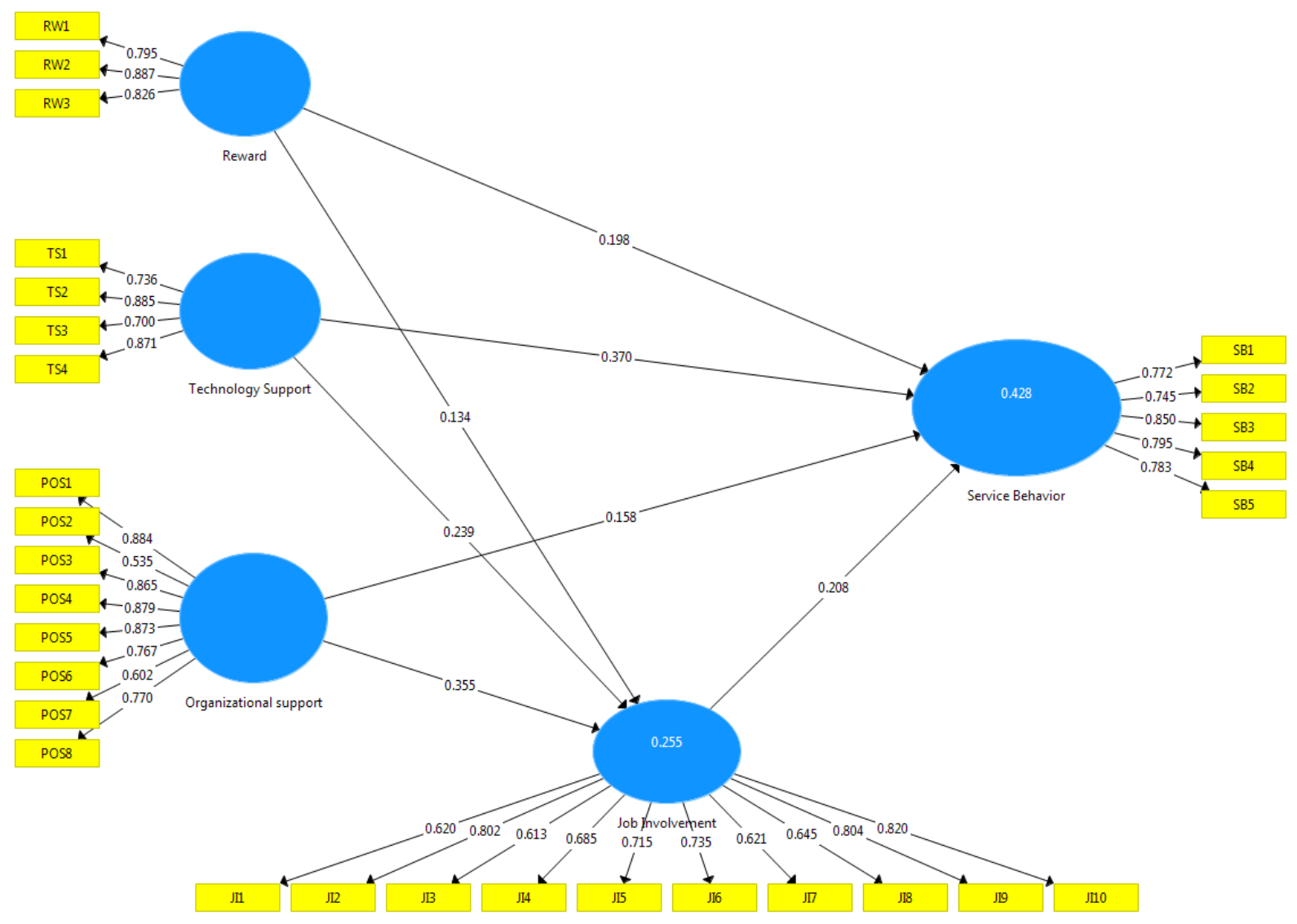

Figure 2: Factor loadings

Table 3: Correlations, reliability and validity of the constructs

\begin{tabular}{|l|c|c|c|c|c|c|c|c|}
\hline Variable & 1 & 2 & 3 & 4 & 5 & $\alpha$ & C.R & AVE \\
\hline Job Involvement & .710 & & & & & .891 & .91 & .504 \\
\hline Organizational support & .404 & .782 & & & & .905 & .925 & .612 \\
\hline Reward & .291 & .136 & .837 & & & .785 & .875 & .701 \\
\hline Service Behavior & .458 & .318 & .447 & .790 & & .849 & .892 & .624 \\
\hline Technology Support & .346 & .131 & .452 & .552 & .802 & .816 & .877 & .643 \\
\hline
\end{tabular}

Note: CR: composite reliability; AVE: average variance extracted; $\alpha$ : Cronbach's alpha. Square-root of AVE for each construct in bold.

\section{Common method bias}

The Harman's one factor test is used to examine the potential problem of common method variance. All items were entered into EFA which is forced to produce one factor. The result suggested that the factor accounts for only $21.25 \%$ of the total variance. Therefore, common method bias does not pose a significant problem in this study.

\subsection{Hypothesis testing}

Hypotheses H1a to H1c concern the direct impact of management commitment to service quality on car-hailing drivers' service behaviors. Specifically, reward, technology support and organizational support are each expected to positively and significantly predict service behaviors. These hypotheses were tested based on the significance of 
the structural path coefficients. As indicated in Table 4, the path coefficients from reward $(\beta=.198, \mathrm{p}<.05)$, technology support $(\beta=.370, p<.001)$ and organizational support $(\beta=.158, p<.05)$ are all positive and significant. Therefore, hypotheses from H1a to H1c are supported.
Table 4 showed that the path coefficients from reward, technology support and organizational support to Job involvement are all positive and significant, supporting hypotheses $\mathrm{H} 2 \mathrm{a}$ to $\mathrm{H} 2 \mathrm{c}$.

Table 4: Direct effects of management commitment to service quality on service behavior and job involvement

\begin{tabular}{|l|l|l|}
\hline Direct effect & Service behavior & Job Involvement \\
\hline Reward & $.198^{*}$ & $.124^{*}$ \\
\hline Technology support & $.370^{* * *}$ & $.239 * *$ \\
\hline Organizational support & $.158^{*}$ & $.355^{* * *}$ \\
\hline
\end{tabular}

Note: CR: composite reliability; AVE: average variance extracted; $\alpha$ : Cronbach's alpha. Square-root of AVE for each construct in bold.

Hypotheses $\mathrm{H} 3 \mathrm{a}$ to $\mathrm{H} 3 \mathrm{c}$ suggest that Job involvement mediates the relationship between three dimensions of MCSQ and Service behaviors. To test the hypotheses, the 4 steps suggested by Baron and Kenny (1986) are followed. The conditions for mediation need to be checked before making conclusion. The first two conditions for mediation are that the independent variables must be significantly associated with the mediator (job involvement) and the dependent variable (service behaviors). These conditions have been satisfied with the support of Hypothesis H1a to $\mathrm{H} 1 \mathrm{c}$ and $\mathrm{H} 2 \mathrm{a}$ to $\mathrm{H} 2 \mathrm{c}$. The third condition was also met when the mediator significantly influences the dependent variable $(\beta=.208, p<.05)$. The indirect effects of reward, technology support and organizational support on service behaviors via job involvement are indicated in Table 5 . The data provide support for $\mathrm{H} 3 \mathrm{~b}$ and $\mathrm{H} 3 \mathrm{c}$ but not for $\mathrm{H} 3 \mathrm{a}$.

Table 5: Indirect effect of MCSQ on service behaviors via job involvement

\begin{tabular}{|l|c|c|c|}
\hline Indirect effect & Coefficient & $\mathrm{t}$ & $\mathrm{p}$ value \\
\hline Reward -> Job Involvement -> Service behaviors & .028 & 1.485 & .138 \\
\hline Technology support -> Job Involvement -> Service behaviors & .050 & 1.978 & .049 \\
\hline Organizational support -> Job Involvement -> Service behaviors & .074 & 2.302 & .022 \\
\hline
\end{tabular}

\section{Discussion and contribution}

\subsection{Discussion}

This study aims to investigate the impacts of MCSQ on service behaviors among GrabCar drivers. Because of the generally agreed non-employment relationship between Transportation Network Companies and their drivers, it is important to understand how these TNCs can improve service quality by influencing their drivers.

The result showed that reward is associated with service behaviors among car-hailing drivers. Specifically, the impact of management commitment to service quality, manifesting in the reward system that is contingent upon service delivery, is positively influence the delivery of service as expected by the TNCs. In the car-hailing context, income is among the primary reasons for individuals to become a driver (Standing et al., 2019; Valente et al., 2019).
If the drivers perceive that their income is directly linked with their service delivery, they are likely to devote more effort in providing excellent service. The results are in line with the findings of previous research in the car-hailing context. Fielbaum and Tirachini (2020) found that wage level and the transparency in wage determination are the top two predictors of job satisfaction among ride-hailing drivers in Chile. On the other hand, inadequate pay and perceived pay injustice are among the causes for drivers' dissatisfaction (Karn \& Hutson, 2019).

The availability of technology support has been found to be an important determinant of service behavior among car-hailing drivers. Because Car-hailing service is a technology-based transportation service, the role of technology support is paramount. Technology helps connect the drivers and passengers, calculate fares and locate the best possible routes. However, despite the overall utility of the app, problems usually arise due to GPS failure or slow update. In addition, drivers report that they did not receive 


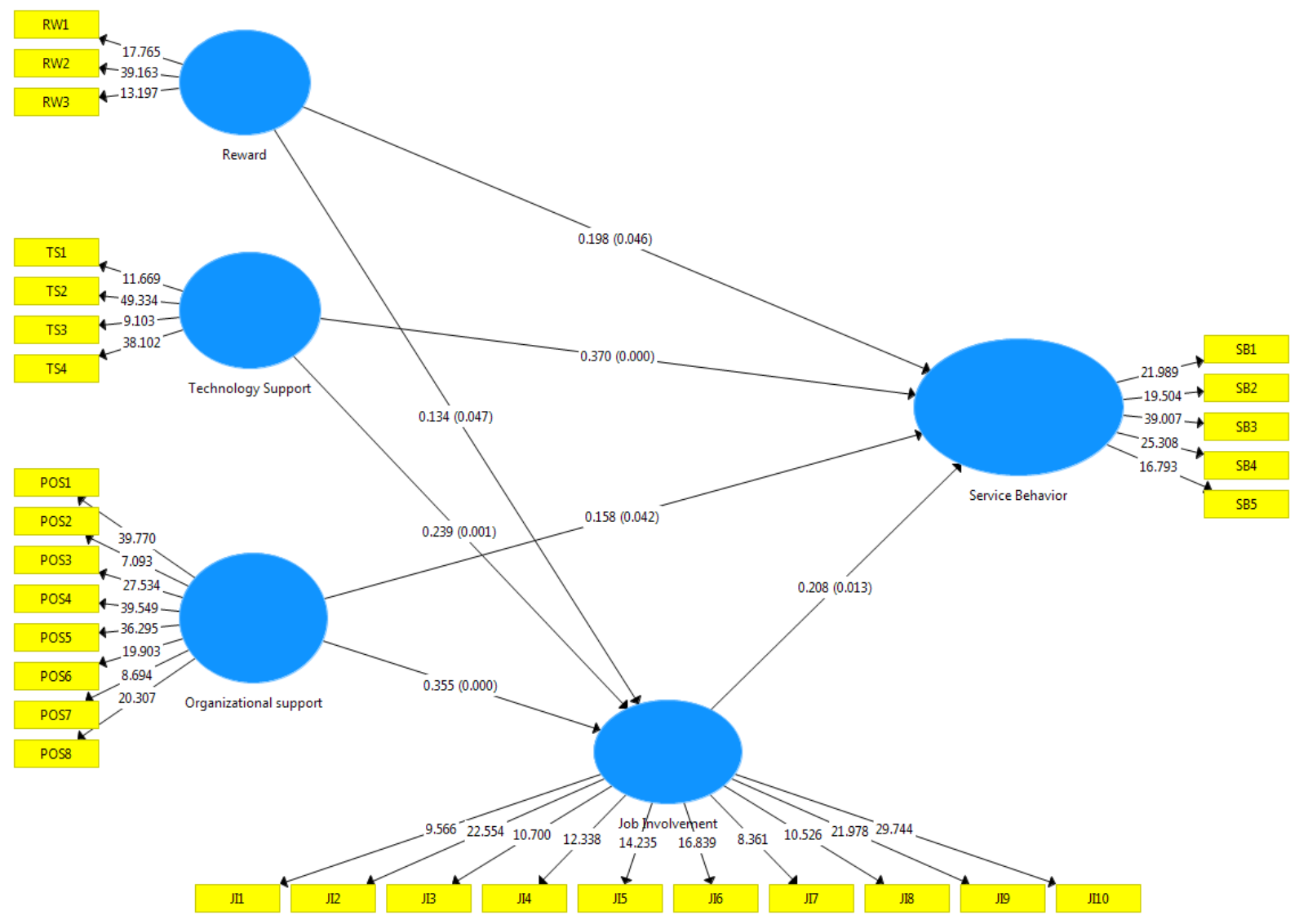

Figure 3: Path coefficients and p-value

much support in dealing with customers beyond the scope of the app (Rosenblat et al., 2017). Other studies highlight the role of trip characteristics, weather conditions, and socioeconomics and demographic factors on car-hailing service accessibility, as well as, service performance indicators such as pick-up waiting time, trip duration, and fare increase (Shokoohyar, Sobhani, \& Sobhani, 2020; Shokoohyar, Sobhani, \& Nargesi, 2020). The findings emphasize the importance of technology support in regulating supply of car-hailing service in order to improve service performance.

Despite the loose relationship between TNCs and drivers, this study suggests that organizational support is a crucial factor in fostering service delivery among drivers. In the context of sharing economy, Liu et al. (2020) found that organizational support, in the forms of psychological contract fulfillment, directly influences gig workers' task performance. Similarly, Gleim et al. (2019) reported that organizational trust is an important predictor of job outcome status and satisfaction among sharing economy workers. Furunes and Mkono (2019) also pointed out that lack of organizational support is the main challenges for food-delivery workers, especially in case of service failure.

Job involvement refers to the personal identification with the current job. Factors that make the job more interesting and enjoyable and those that reduces obstacles and strains in doing the job are expected to increase job involvement. The findings add to previous evidences regarding the antecedents of job involvement in sharing economy context. Fielbaum and Tirachini (2020) indicate that "enjoy driving" was an important predictor of car-hailing drivers' job satisfaction, second only to flexibility.

Job involvement partially mediates the impact of perceived organizational support and technology support on service behaviors. Individuals with high job involvement tend to find the satisfaction of needs in the job. Delivery excellence service is an important mechanism to satisfy both current and long-term needs. Although reward is significantly related to both job involvement and service behaviors, and job involvement affects service behaviors, the indirect effect of reward on service behavior is not significant. A possible explanation lies in that job involvement refers to the degree to which the person places the 
job at the center of his life. Wood (1974) suggested that job involvement results from intrinsic motivation and therefore, is likely to be linked to factors that provides intrinsic rewards. Lin et al. (2020) also concluded that although many workers in the sharing economy aim for earning quick money, it is often their obligation norm rather than the monetary benefits which determine their career commitment. Therefore, although extrinsic reward may have impact on job involvement, other characteristics of the job and the job-environment may contribute much more to job involvement.

\subsection{Theoretical contributions}

The current research concerns the relationship between MCSQ and direct service providers' service delivery in a sharing economy context. While previous research explores the impact of MCSQ in traditional employment settings, few looks to test these impacts in a non-traditional employment context such as car-hailing service. This study suggests that MCSQ can exert positive influence on frontline employees in other service industries.

Second, the current study is one of the few attempts to investigate the mediating role of job involvement in the relationships between MCSQ and service behaviors. Other research examines the mediation role of organizational commitment on the above linkage. The nature of the relationship between TNCs and their drivers undermines the mediating role of such variables as organizational commitment. Because independence and flexibility distinguishes car-hailing service from other transportation services, the role of job involvement in service quality may be of greater interests than organizational commitment.

\subsection{Practical Implications}

In order to motivate drivers to improve service quality, which, in turn lead to customer satisfaction and profit, Grab can take several courses of action as follows. First, upgrading the platform and software to enhance the transparency of the rating system and allow drivers' participation in the performance evaluation process may enhance the perception that the reward system is contingent upon service performance. Currently, although many platforms use rider's rating to measure service quality, many drivers do not believe such ratings influence their incomes. Second, technology support should be improved in order to assist the drivers in dealing with service issues and to prevent service failure. The need to contact call centers or filling paperwork could reduce the attractiveness of this form of work and cause role strain or job stress, which eventually reduce service performance. Finally, providing other kind of support such as family oriented support, service training, and insurance could enhance the drivers' involvement in the job. Highly involved drivers are likely to provide excellent service.

\section{Conclusions and limitations}

\subsection{Conclusions}

This study expands previous research on MCSQ from traditional service industries to the context of sharing economy. In car-hailing context, the direct service providers are responsible for the delivery of high quality service to end users and receive performance feedback from end users via the form of star-ratings (Grab, 2019). The end-users are in fact, evaluate the quality of service delivered by drivers rather the quality of service provided by Transport Network Companies. TNCs, in turn, influence service quality by adopting reward and punitive policies based on star-ratings (Shokoohyar, 2018). Although, customers do not directly rate a TNC's service, it is likely that they will switch to a TNC's competitors if they constantly receive poor service from drivers associated with this TNC. Therefore, TNCs should encourage their drivers to improve their service quality. In addition, because TNCs are competing for the service of drivers, they need provide support for their drivers.

This research reveals that by showing their commitment to service quality, TNCs can influence service quality provided by their affiliated drivers. Furthermore, due to the loosely tied nature of the relationship between a TNC and its drivers, providing long-term career, enhancing organizational commitment and creating loyalty are not appropriate. By fostering job involvement among drivers via various forms of technological and psychological support, TNCs could help drivers in improving service quality. Our results can provide insights for future research about service quality in other services in the sharing economy context.

\subsection{Limitations and directions for future research}

The current study seeks to expand current understanding of MCSQ's influence on service behaviors to sharing economy context. However, the findings of this research only focuses on car-hailing service, thus the generalizability of the results is limited. Future research may seek to advance the focus to other sharing economy business models.

Cross-sectional design and single data source are the second limitation of the current research. Because job involvement refers to a state of psychological identification with work, observing it at one point in time may not capture the influence of MSCQ on job involvement overtime. 
Future research may adopt a longitudinal research design to avoid this limitation. In addition, although there has been no severe effect of common method bias in the current paper, it would be desirable to collect data from multiple sources such as management of TNCs, peer drivers, and riders in order to yield more robust results.

The current study investigates the mediating role of job involvement in the MSCQ-service behaviors linkage. Because literature has suggested that people participate in the sharing economy for both extrinsic and intrinsic motivation, exploring other mechanisms that transfers the impact of sharing platform management practices on participants' behaviors is, therefore, require further research attentions.

\section{Literature}

Abdallah, A.B., Phan, A.C., \& Matsui, Y. (2016). Investigating the effects of managerial and technological innovations on operational performance and customer satisfaction of manufacturing companies. International Journal of Business Innovation and Research, 10 (2/3), 153-183. https://doi.org/10.1504/ IJBIR.2016.074824

Abhari, K., Davidson, E.J., \& Xiao, B. (2019). Collaborative innovation in the sharing economy: Profiling social product development actors through classification modeling. Internet Research, 29(5), 1014-1039. https://doi.org/10.1108/INTR-03-2018-0129

Ahrholdt, D. C., Gudergan, S. P., \& Ringle, C. M. (2017). Enhancing Service Loyalty: The Roles of Delight, Satisfaction, and Service Quality. Journal of Travel Research, 56(4), 436-450. https://doi. org/10.1177/0047287516649058

Albalawi, A.S., Naughton, S., Elayan, M.B., \& Sleimi, M.T. (2019). Perceived Organizational Support, Alternative Job Opportunity Organizational Commitment, Job Satisfaction and Turnover Intention: A Moderated-mediated Model. Organizacija, 52(4), 310-324. https://doi.org/10.2478/orga-2019-0019.

Amey, A., Attanucci, J., \& Mishalani, R. (2011). Real-Time Ridesharing: Opportunities and Challenges in Using Mobile Phone Technology to Improve Rideshare Services. Transportation Research Record, 2217(1), 103-110. https://doi.org/10.3141/2217-13

An, S., Suh, J., \& Eck, T. (2019). Examining structural relationships among service quality, perceived value, satisfaction and revisit intention for Airbnb guests. International Journal of Tourism Sciences, 19(3), 145165. https://doi.org/10.1080/15980634.2019.1663980

Ashill, N.J., Rod, M., \& Carruthers, J. (2008). The Effect of Management Commitment to Service Quality on Frontline Employees' Job Attitudes, Turnover Intentions and Service Recovery Performance in a New Public Management Context. Journal of Strategic Marketing, 16(5), 437-462. https://doi. org/10.1080/09652540802480944

Babakus, E., Yavas, U., Karatepe, O. M., \& Avci, T. (2003). The effect of management commitment to service quality on employees' affective and performance outcomes. Journal of the Academy of Marketing Science, 31(3), 272-286. http://dx.doi.org/10.1177/00920 70303031003005

Baron, R. M., \& Kenny, D. A. (1986). The moderator-mediator variable distinction in social psychological research: Conceptual, strategic, and statistical considerations. Journal of Personality and Social Psychology, 51(6), 1173-1182.

Çetin, T. (2017). The Rise of Ride Sharing in Urban Transport: Threat or Opportunity? in H. Yaghoubi (Ed.), Urban Transport Systems. Rijeka: InTech, pp. 191-202. https://doi.org/10.5772/66918

Chen, C. C., \& Chiu, S. F. (2009). The mediating role of job involvement in the relationship between job characteristics and organizational citizenship behavior. The Journal of Social Psychology, 149(4), 474-494. https:// doi.org/10.3200/SOCP.149.4.474-494

Dabholkar, P.A. (2000). Technology in service delivery: Implications for self-service and service support, in T.A. Swartz and D. Iacobucci (Eds.), Handbook of services marketing and management, Thousand Oaks, CA: Sage, 103-110.

Dias, F.F., Lavieri, P.S., Garikapati, V.M., Astroza, S., Pendyala, R.M., \& Bhat, C.R. (2017). A behavioral choice model of the use of car-sharing and ride-sourcing services. Transportation, 44(6), 1307-1323. https://doi. org/10.1007/s11116-017-9797-8

Diefendorff, J. M., Brown, D. J., Kamin, A. M., \& Lord, R. G. (2002). Examining the roles of job involvement and work centrality in predicting organizational citizenship behaviors and job performance. Journal of Organizational Behavior, 23(1), 93-108. https://doi. org/10.1002/job.123.

Dimitriades, Z. S. (2007). The influence of service climate and job involvement on customer oriented organizational citizenship behavior in Greek service organizations: A survey. Employee Relations, 29(5), 469-491. https://doi.org/10.1108/01425450710776290

Eisenberger, R., Huntington, R., Hutchison, S., \& Sowa, D. (1986). Perceived organizational support. Journal of Applied Psychology, 71(3), 500-507. https://doi. org/10.1037/0021-9010.71.3.500

Fielbaum, A., \& Tirachini, A. (2020). The sharing economy and the job market: the case of ride-hailing drivers in Chile. Transportation, (June 2020). https://doi. org/10.1007/s11116-020-10127-7

Fornell, C., \& Larcker, D. F. (1981). Evaluating structural equation models with unobservable variables and 
measurement error. Journal of Marketing Research, 18(1), 39-50. https://doi.org/10.2307/3151312

Frei, F.X. (2008). The four things a service business must get right. Harvard Business Review, 86(4), pp. 70-80.

Furunes, T., \& Mkono, M. (2019). Service-delivery success and failure under the sharing economy. International Journal of Contemporary Hospitality Management, 31(8), 3352-3370. https://doi.org/10.1108/ IJCHM-06-2018-0532

Gleim, M.R., Johnson, C.M., \& Lawson, S.J. (2019). Sharers and sellers: A multi-group examination of gig economy workers' perceptions. Journal of Business Research, 98 (May 2019), 142-152. https://doi. org/10.1016/j.jbusres.2019.01.041

Grab, (2019). Update on Cancellation Policy. Retrieved from https://www.grab.com/ph/blog/update-on-cancellation-policy. April 26th, 2019.

Hair, J.F., Black, W.C., Babin, B.J. \& Anderson, R.E. (2010). Multivariate Data Analysis. 7th Edition, Pearson, New York.

Hamenda, A. (2019). An integrated model of service quality, price fairness, ethical practice and customer perceived values for customer satisfaction of sharing economy platform. International Journal of Business and Society, 19(3), 709-724.

Hogan, N. L., Lambert, E. G., \& Griffin, M. L. (2013). Loyalty, Love, and Investments: The Impact of Job Outcomes on the Organizational Commitment of Correctional Staff. Criminal Justice and Behavior, 40(4), 355-375. https://doi.org/10.1177/0093854812469944

Ju, Y., Back, K.J, Choi, Y., \& Lee, J.S. (2019). Exploring Airbnb service quality attributes and their asymmetric effects on customer satisfaction. International Journal of Hospitality Management, 77(1), 342-352. https:// doi.org/10.1016/j.ijhm.2018.07.014

Kandampully, J., \& Menguc, B. (2000). Managerial practices to sustain service quality: an empirical investigation of New Zealand service firms. Marketing Intelligence and Planning, 18(4), 175-184. https://doi. org/10.1108/02634500010333299

Kanungo, R. (1982). Measurement of job and work involvement. Journal of Applied Psychology, 67(3), 341349. https://doi.org/10.1037/0021-9010.67.3.341

Karatepe, O.M., \& Karadas, G. (2012). The effect of management commitment to service quality on job embeddedness and performance outcomes. Journal of Business Economics and Management, 13(4), 614-636. https://doi.org/10.3846/16111699.2011.620159

Karn, K.S., \& Hutson, W.E. (2019). Getting Us There Ride-Hailing Systems from the Drivers' Perspectives. Ethnographic Praxis in Industry Conference Proceedings, 302-317. https://doi.org/10.1111/15598918.2019.01287

Katz, V. (2015) 'Regulating the sharing economy', Berkeley Technology Law Journal, 30(385), 1067-1126.
Kim, H. J., Tavitiyaman, P., \& Kim, W. G. (2009). The effect of management commitment to service on employee service behaviors: the mediating role of job satisfaction. Journal of Hospitality and Tourism Research, 33(3), 369-390. https://dx.doi. org/10.1177/1096348009338530

Lambert, E. G., \& Paoline, E. A. III. (2012). Exploring potential antecedents of job involvement: An exploratory study among jail staff. Criminal Justice and Behavior, 39(3), 264-286. https://doi. org $/ 10.1177 / 0093854811433533$

Lawler, E., \& Hall, D. (1970). Relationship of job characteristics to job involvement, satisfaction, and intrinsic motivation. Journal of Applied Psychology, 54(4), 305-312. https://doi.org/10.1037/h0029692

Lawler, E. (1992). The ultimate advantage: Creating the high-involvement organization, San Francisco: Jossey-Bass.

Lee, S., Barker, S., \& Kandampully, J. (2003). Technology, service quality, and customer loyalty in hotels: Australian managerial perspectives. Managing Service Quality: An International Journal, 13(5), 423-432. https:// doi.org/10.1108/09604520310495886

Lin, Pearl. M.C, Au, W.C., Leung, Vicky. T.Y., \& Peng, K.L. (2020). Exploring the meaning of work within the sharing economy: A case of food-delivery workers. International Journal of Hospitality Management, 91 (102686). https://doi.org/10.1016/j.ijhm.2020.102686.

Liu W, He C, Jiang Y, Ji R., \& Zhai X. (2020). Effect of Gig Workers' Psychological Contract Fulfillment on Their Task Performance in a Sharing Economy-A Perspective from the Mediation of Organizational Identification and the Moderation of Length of Service. International Journal of Environmental Research and Public Health, 17(7):2208. https://doi.org/10.3390/ ijerph17072208

Lytle, R.S., Hom, P.W., \& Mowka, M.P. (1998). SERV*OR: Managerial measures of organizational service orientation. Journal of Retailing, 74(4), 1-15. https://doi. org/10.1016/S0022-4359(99)80104-3

Mrayyan, M.T., \& Al-Faouri, I. (2008). Predictors of career commitment and job performance of Jordanian nurses. Journal of Nursing Management, 16, 246-256. https://doi.org/10.1111/j.1365-2834.2007.00797.x

Parasuraman, A. (1987). Customer-oriented corporate cultures are crucial to services marketing success. Journal of Services Marketing, 1(1), 39-46. https://doi. org/10.1108/eb059587

Peticca-Harris, A., deGama, N., \& Ravishankar, M. N. (2020). Post-capitalist precarious work and those in the 'drivers' seat: Exploring the motivations and lived experiences of Uber drivers in Canada. Organization, 27(1), 36-59. https://doi.org/10.1177/1350508418757332

Priporas, C.V., Stylos, N. Vedanthachari, L.N., \& Santiwatana, P. (2017). Service quality, satisfaction, and 
customer loyalty in Airbnb accommodation in Thailand. International Journal of Tourism Research, 19(6), 693-704. https://doi.org/10.1002/jtr.2141

Priporas, C.V., Stylos, N., Rahimi, R., \& Vedanthachari, L. (2017). Unraveling the diverse nature of service quality in a sharing economy: A social exchange theory perspective of Airbnb accommodation. International Journal of Contemporary Hospitality Management, 29(9), 2279-2301. https://doi.org/10.1108/ IJCHM-08-2016-0420

Rayle, L., Dai, D., Chan, N., Cervero, R., \& Shaheen, S. (2016). Just a better taxi? A survey-based comparison of taxis, transit, and ride-sourcing services in San Francisco. Transport Policy, 45(1), 168-178. https://doi. org/10.1016/j.tranpol.2015.10.004

Rhoades, L., \& Eisenberger, R. (2002). Perceived organizational support: A review of the literature. Journal of Applied Psychology, 87(4), 698-714. https://doi. org/10.1037/0021-9010.87.4.698

Rod, M., \& Ashill, N.J. (2010). Management commitment to service quality and service recovery performance: A study of frontline employees in public and private hospitals. International Journal of Pharmaceutical and Healthcare Marketing, 4(1), 84-103. https://doi. org/10.1108/17506121011036042

Rosenblat, A., \& L. Stark. (2016). Algorithmic Labor and Information Asymmetries: A Case Study of Uber's Drivers. International Journal of Communication, 10, 3758-3784.

Rosenblat, A., Levy, K.E., Barocas, S., \& Hwang, T. (2017). Discriminating Tastes: Uber's Customer Ratings as Vehicles for Workplace Discrimination. Policy \& Internet, 9(3), 256-279. https://doi.org/10.1002/ poi3.153

Shokoohyar, S. (2018). Ride-sharing platforms from drivers' perspective: Evidence from Uber and Lyft drivers. International Journal of Data and Network Science, 2(4), 89-98. https://doi.org/10.5267/j. ijdns.2018.10.001

Shokoohyar, S, Sobhani, A., \& Ramezanpour Nargesi, SR (2020). On the determinants of Uber accessibility and its spatial distribution: Evidence from Uber in Philadelphia. WIREs Data Mining Knowledge Discovery, 10(4), 1-15. https://doi.org/10.1002/widm.1362

Shokoohyar, S, Sobhani, A., \& Sobhani, A. (2020). Impacts of trip characteristics and weather condition on ride-sourcing network: Evidence from Uber and Lyft. Research in Transportation Economics, 80 (100820). https://doi.org/10.1016/j.retrec.2020.100820

Standing, C., Standing, S., \& Biermann, S. (2019). The implications of the sharing economy for transport. Transport Reviews, 39(2), 226-242. https://doi.org/10.1080/ 01441647.2018 .1450307

Susskind, A. M., Borchgrevink, C. P., Kacmar, K. M., \& Brymer, R. A. (2000). Customer service employees' behavioral intentions and attitudes: An examination of construct validity and a path model. International Journal of Hospitality Management, 19(1), 53-77. https://doi.org/10.1016/S0278-4319(99)00030-4

Uber (2019). Introducing Uber Pro. Retrieved from https://www.uber.com/us/en/drive/uber-pro. Accessed on 29 Feb. 2020.

Ueno, A. (2008). Is empowerment really a contributory factor to service quality? The Service Industries Journal, 28(9), 1321-1337. https://doi. org $/ 10.1080 / 02642060802230262$

Valente, E., Patrus, R., \& Córdova Guimarães, R. (2019). Sharing economy: becoming an Uber driver in a developing country. Revista de Gestão, 26(2), 143-160. https://doi.org/10.1108/REGE-08-2018-0088

Wood, D. A. (1974). Effects of worker orientation differences on job attitude correlates. Journal of Applied Psychology, 59(1), 54-60. https://doi.org/10.1037/ h0035829

Yang, S., Song, Y., Chen, S., \& Xia, X. (2017). Why are customers loyal in sharing-economy services? A relational benefit perspective. Journal of Services Marketing, 31(1), 48-62. https://doi.org/10.1108/JSM-012016-0042

Yavas, U., Karatepe, O.M., Avci, T., \& Tekinkus, M. (2003). Antecedents and outcomes of service recovery performance: an empirical study of frontline employees in Turkish banks. The International Journal of Bank Marketing, 21(4/5), 255-65. https://doi. org/10.1108/02652320310488439

Zervas, G., Proserpio, D., \& Byers, J. W. (2017). The Rise of the Sharing Economy: Estimating the Impact of Airbnb on the Hotel Industry. Journal of Marketing Research, 54(5), 687-705. https://doi.org/10.1509/ jmr.15.0204

Zhang, N., Li, M., Gong, Z., \& Xu, D. (2019). Effects of ethical leadership on nurses' service behaviors. Nursing Ethics, 26(6), 1861-1872. https://doi. org/10.1177/0969733018787220

Zuo, W., Zhu, W., Chen, S., \& He, X. (2019). Service quality management of online car-hailing based on PCN in the sharing economy. Electronic Commerce Research and Application, 34, Article 100827. https:// doi.org/10.1016/j.elerap.2019.100827 
Phuong Tran Huy is an assistant professor who currently works at Faculty of Human Resource Economics and Management, National Economics University, Hanoi Vietnam. Phuong holds a Ph.D. degree in management from Kobe University, Hyogo, Japan. Phuong does research in Organizational Behavior, Human Resources Management and Labor Economics. Phuong's current project is "High performance work system in Vietnam".
Hong Chuong Pham is an Associate Professor, who has been working for more than 30 years at the National Economics University (NEU) in Vietnam as a lecturer in Tourism and Hospitality Management. Chuong has authored and co-authored numerous papers in Tourism Economics, Tourism and Hospitality Management and Tourism Development. 


\section{Appendix}

\section{Service-based reward system}

1. I receive positive recognition from Grab when I excel in serving customers.

2. Grab has financial incentives for service excellence.

3. My income depends on the quality of service I deliver.

\section{Service technology support}

1. Grab has the necessary technology support to serve my customers effectively.

2. Grab has 'state of the art' technology to enhance our service quality.

3. Grab allocates a significant amount of money on technology to support my efforts to deliver effective service.

4. Grab works hard to make our systems and processes more customer friendly.

\section{Perceived organizational support}

1. Grab values my contribution to its well-being.

2. Grab fails to appreciate any extra effort from me. (Reverse)

3. Grab would ignore any complaint from me. (Reverse)

4. Grab really cares about my well-being.

5. Even if I did the best job possible, Grab would fail to notice. (Reverse)

6. Grab cares about my general satisfaction at work.

7. Grab shows very little concern for me. (Reverse)

8. The organization takes pride in my accomplishments at work

\section{Job involvement}

1. The most important things that happen to me involve my present job.

2. To me, my job is only a small part of who I am. (Reverse)

3. I am very much involved personally in my job.

4. I live, eat and breathe my job.

5. Most of my interests are centered around my job.

6. I have very strong ties with my present job which would be very difficult to break.

7. Usually I feel detached from my job. (Reverse)

8. Most of my personal life goals are job-oriented.

9. I consider my job to be very central to my life.

10. I like to be really involved in my job most of the time.

\section{Service behavior}

1. I provide transportation services according to the job responsibilities prescribed by Grab

2. I am familiar with the service procedures of different car-hailing requests.

3. I can independently fulfill responsibilities to customers as specified in my job description.

4. I can satisfy the needs of customers with pleasure in my duties.

5. I have the good manners as a driver with neat and professional appearance. 